\title{
ОГЛЯД ТА АНАЛІЗ КОНСТРУКЦЙ УСТАНОВОК ДЛЯ ОТРИМАННЯ НАНОЧАСТИНОК ВУГЛЕЦЮ ЕЛЕКТРОДУГОВИМ МЕТОДОМ
}

Кандидати техн. наук С.В. Воронін, Д.В. Онопрейчук, інж. О.О. Суранов, Д.О. Амінов

\section{ОБЗОР И АНАЛИЗ КОНСТРУКЦИЙ УСТАНОВОК ДЛЯ ПОЛУЧЕНИЯ НАНОЧАСТИЦ УГЛЕРОДА ЭЛЕКТОРОДУГОВЫМ МЕТОДОМ}

Кандидаты техн. наук С.В. Воронин Д.В. Онопрейчук, инж. А.А. Суранов, Д.А. Аминов

\section{REVIEWS AND ANALISYS OF DESINGS FOR RECEIVE OF CARBONS NANOPARTICULARS BY ELECTRICAL ARC METHOD}

Cand. of techn. sciences S.V. Voronin, cand. of techn. sciences D.V. Onopreychuk, eng. A.A. Suranov, D.A. Aminov

У роботі наведені результати патентного пошуку та огляд конструкцій установок для отримання високоструктурованих наночастинок вуглецю (ВНВ) електродуговим методом. Виявлено основні переваги й недоліки існуючих конструкиій. 3 урахуванням унікальних властивостей ВНВ вони можуть використовуватися в транспортному машинобудуванні.

Ключові слова: наночастки вуглечю, електродуговий метод, фізичні властивості наночасток.

В работе приведены результаты патентного поиска и обзор конструкций установок для получения высокоструктурированных наночастиц углерода (ВНУ), фуллеренов. Выявлены основные преимущества и недостатки существующих конструкций. С учетом уникальных свойств ВНУ они могут быть использованы в транспортном машиностроении.

Ключевые слова: наночастицы углерода, электродуговой метод, физические свойства наночастиц. 
The paper presented the results of a patent search and review of plant designs for visokostrukturovanih nanochastok carbon (VNC), fulereniv and more. The basic advantages and disadvantages of the existing structures. Given the unique properties of the VNC, they can have on transport engineering. Of particular interest is the possibility to adjust the initial value of the products obtained by regulating VNC on parameters such as current combustion electrodes, the voltage at the electrodes of the last feed rate, the inert gas pressure in the reactor, the distance between the electrodes and so on. With the control of parameters we have significantly changed the course of the combustion reaction of the electrodes as well as have the ability to program and control the reaction, in order to receive a specified or required nanoproduct the previous defined parameters.

Keywords: nanoparticles carbon, electric-method, physical properties of nanoparticles.

Постановка проблеми. Відкриття фулеренів у 1985 році викликало величезний інтерес у науковому співтоваристві, із цього моменту ці вуглецеві наночастинки привертають до себе все більшу та більшу увагу. Основою для одержання фулеренів $\epsilon$ високотемпературні пари вуглецю. Дотепер було відомо два основних алотропних стани вуглецю: 3D форма (структура алмазу) і шарувата - 2D форма (структура графіту). В 1985 р. Харольдом Крото й Ричардом Смолі була відкрита 0D форма, що складається 360 атомів вуглецю, названа фулеренами. Це відкриття було відзначено Нобелівською премією з хімії. А в 1991 році Ііжима виявив нову 1D форму вуглецю - довгасті трубчасті вуглецеві утворення, названі нанотрубками [1].

Результати попередніх досліджень властивостей наночастинок вуглецю $\mathrm{y}$ вигляді нанотрубок, графенів, фулеренів показали, що їх використання в трибовузлах машин приводить до зниження коефіцієнта тертя у 2-2,5 раза.

Існуючі на сьогодні способи та пристрої виробництва для одержання високоструктурованих наночастинок вуглецю (ВНВ) не дозволяють виробляти їх у достатній кількості для досліджень і застосування. Крім того, ВНВ мають високу собівартість у виробництві.

Тому розробка нових способів i пристроїв $є$ актуальним завданням.

Нижче наведений огляд та аналіз наявних на сьогодні конструкцій пристроїв для одержання ВНB методом електродугового випарювання гарфіту в атмосфері інертних газів.

Однією 3 досконалих конструкцій реакторів для одержання ВНВ є пристрій, показаний на рис. 1 [2], який використовує електродуговий розряд постійного струму між вуглецевим анодом i катодом у герметичному реакторі 3 інертною атмосферою, систему пересування фулеренової сажі 3 реактора окремим потоком інертного газу.

Сажа осаджується на поверхні охолоджуваних водою трубок, здувається потоком інертного газу в посудини 3 толуолом (метод барбатації). Газ повертається в реактор.

Особливість пристрою полягає в тому, що один 3 електродів 6 (графітовий анод) має можливість поступального переміщення, а другий електрод виконаний у вигляді мідного охолоджуваного циліндра 2, діаметром учетверо більше графітового анода, що має можливість обертання навколо своєї осі. Крім того пристрій оснащений шкребком для очищення катода від депозиту.

Перевагою даного способу та пристрою $\epsilon$ наявність охолоджуваних радіаторів усередині реактора, а також осадження сажі відразу в толуолові посудини. Це дає можливість розділяти графени, нанотрубки, фулерени й графітову сажу.

Недоліками зазначеного пристрою є:

- великі втрати вуглецю на утворення депозиту на катоді; 
- неможливість

безперервного процесу та подачі окремого потоку інертного газу;
- відсутній бункер для збору недогарків електродів;

- немає фільтра для толуолу, який має можливість потрапляння в камеру реактора.

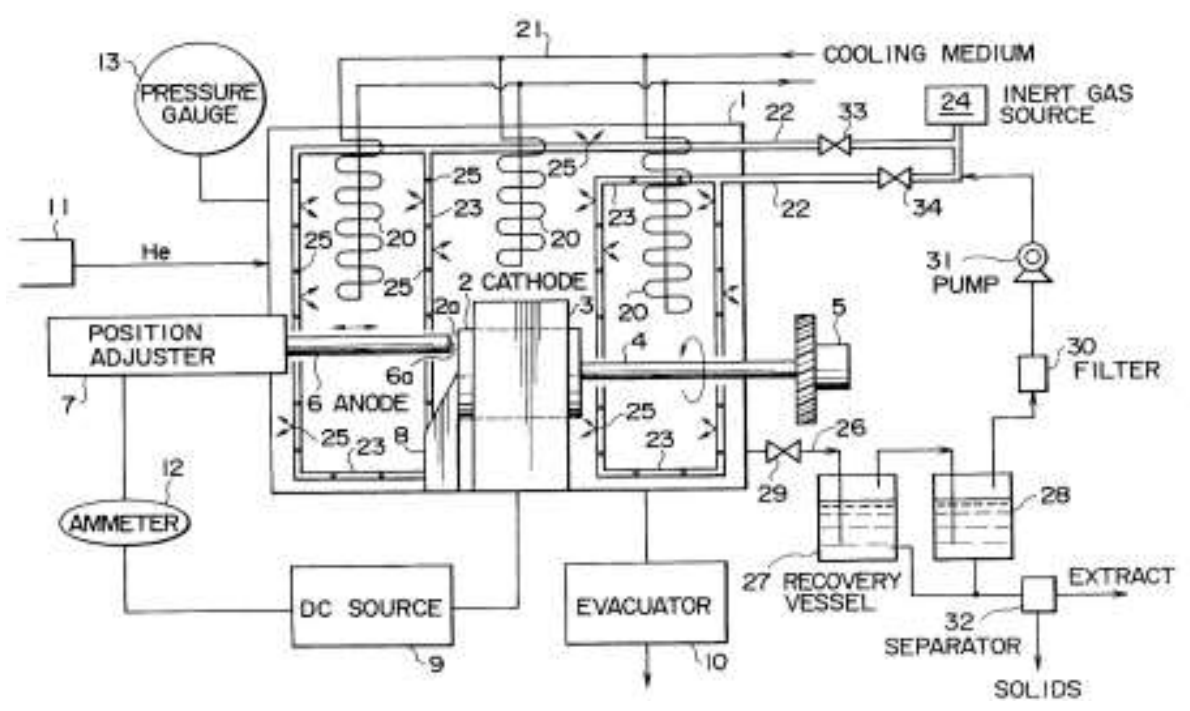

Рис. 1. Пристрій для виробництва ВНВ:

1 - камера; 2 - катод; 2а - поверхні катода; 3 - опорний елемент; 4 - вал; 5 - приводний механізм; 6 - анод; 6а - верхній кінець анода; 7 - регулятор; 8 - шкребок; 9 - джерело постійного струму; 10 - евакуатор; 11 - джерело; 12 - амперметр; 13 - манометр; 20 - охолоджувач; 21 - рециркуляційний трубопровід; 22 - лінії інертного газу; 23 трубки; 24 - джерело інертного газу; 25 - отвори; 26 - випускний трубопровід; 27-28 посудини; 29, 33 й 34 - крани; 30 - фільтр; 31 - насос- 32 - сепаратор

Особливістю іншої конструкції реактора для одержання ВНВ є пристрій, показаний на рис. 2 [3], який включає плазмовий реактор у вигляді герметичної циліндричної камери із системою циркуляції інертного газу, із засобом уловлювання фулеренової сажі, 3 розміщеними по осі камери двома графітовими стрижневими електродами, один із яких нерухомо закріплений в охолоджуваному струмопроводі, а інший установлений у другому охолоджуваному струмопроводі 3 можливістю осьового поступального переміщення. Реактор додатково оснащений камерою дегазації рухомого графітового електрода тліючим розрядом, система циркуляції інертного газу оснащена кільцевим щілинним соплом, розміщеним коаксіально електродам, а засіб уловлювання фулеренової сажі оснащено електрофільтром, установленим на вході системи циркуляції інертного газу.

У даному пристрої забезпечується дегазація одного з електродів. До недоліків пристрою відноситься відносно невисока продуктивність по сажі та фулеренам при значних витратах енергії, можливість зриву дуги потоком інертного газу й пропалювання стінки розрядної камери.

У даному пристрої сопла доцільно виконувати із внутрішнім радіусом $\mathrm{R}$ не меншим 45 мм. Вихід сопла може бути встановлений на відстані 30-40 мм від площини, що проходить через центр міжелектродного зазора. Для закручування кільцевого потоку інертного газу сопло оснащено дефлектором. Дефлектор виконаний у вигляді пластин, установлених у соплі під гострим кутом до його осі, або у вигляді напрямних лопаток. 


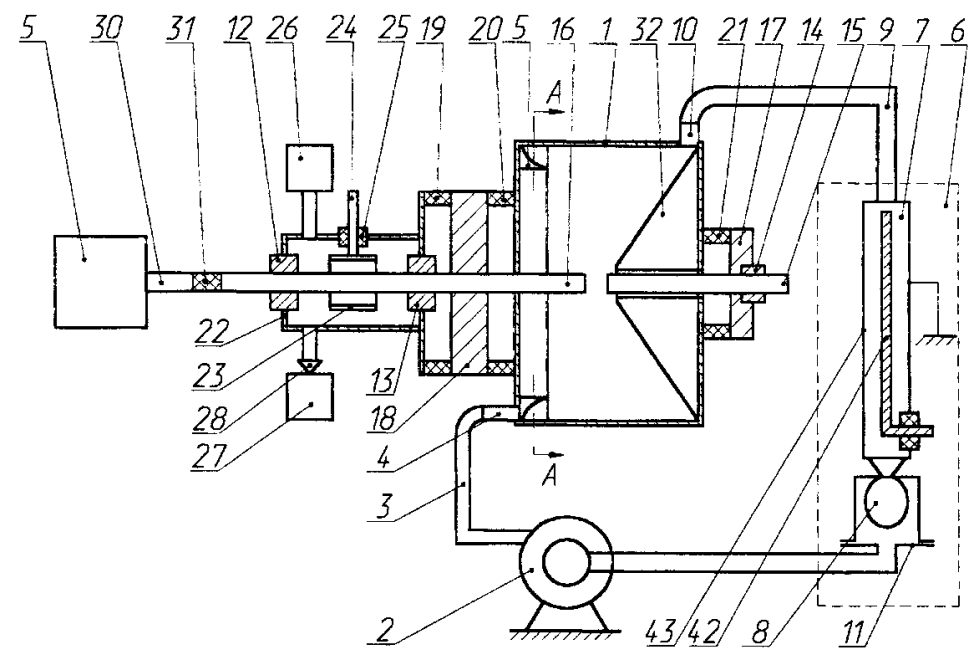

Рис. 2. Схема реактора для одержання ВНВ:

1 - герметична циліндрична камера із системою циркуляції інертного газу, 2 - газовий нагнітач, 3,9 - трубопровід, 4 - штуцер, 5 - кільцеве сопло, 6 - фулеренова сажа, 7 - електрофільтр, 8 - рукавний фільтр, 10 - вихідний патрубок, 11 - вихідний фланець, 12-14 - ущільнення Вільсона, 15, 16 - нерухомий i рухомий електроди, 17-18 - струмопроводи, 19-21 - ізолятори, 22 - камери дегазації, 23 - кільцевий електрод, 24 - вивід, 25 - ізолятор, 26 - форвакуумний насос, 27 - балон інертного газу, 28 - голчастий клапан, 29 - система переміщення, 30 - штовхач, 31 - ізолятор, 32 - конічний екран, 33,36 - сорочка, 34-35,37,38,40-41 - патрубки, 42 - центральний електрод, 43 - заземлений корпус

Недоліками даного пристрою є:

- необхідність періодично зупиняти реактор для очищення рукавного фільтра;

- необхідність змінювати полярність джерела дуги;

- відсутність системи охолодження циркуляційного інертного газу;

- недостатнє очищення циркуляційного інертного газу від фулеренової сажі, що може привести до «отруєння» газу фулереновою сажею.

- неефективне використання дорогих електродів, вони не можуть повністю згоріти через велику відстань між струмопроводами.

Найбільш досконалою конструкцією реактора $є$ пристрій, показаний на рис. 3 [4].

Пристрій містить наступні основні вузли й деталі.

У верхній частині корпуса 1 (рис. 3) є охолоджувана камера 2, виготовлена 3 нержавіючої сталі. Простір 3 між корпусом
1 і камерою 2 служить для циркуляції води, призначеної для охолодження камери 2 (система циркуляції води на кресленні не показана).

Камера 2 приєднана до системи, що забезпечує циркуляцію усередині камери інертного газу, наприклад гелію (система на кресленнях не показана), та сполучена 3 одним або декількома збірниками фулеренової сажі (збірники на кресленнях не показані).

Усередині камери 2 один проти одного розташовані електроди 4 та 5 . Електрод 4 розташований в ізоляторі 6, що виключає електричний контакт електрода 3 камерою 2. Цей же електрод 4 оснащений струмопроводом 7 , змонтованим зовні корпуса 1. Струмопровід 7 електрично підключений до одного $з$ виходів джерела живлення електричної дуги (джерело, електрична дуга та всі електричні з'єднання на кресленні не показані). 
Електрод 5 перебуває в електричному контакті зі струмопроводом 8, який підключений до іншого виходу джерела живлення й установлений в отворі камери, пресування, 9. Остання герметично вмонтована в стінці камери 2. Отвір у камері 9 має поперечний переріз, як у електрода 5.

Камера пресування $9 \in$ частиною шнекового пресу, розміщеного зовні охолоджуваної камери 2. У корпусі 10 преса розташований шнек 11 , що складається із циліндричної i конічної частин. При цьому внутрішня поверхня корпуса 10 повторюе зовнішню конфігурацію шнека 11, забезпечуючи при цьому мінімальний зазор між ними.

Шнек 11 за допомогою свого хвостовика 12, що проходить крізь отвір у нижній частині корпуса 1 , кінематично пов'язаний із приводом обертання 13, розташованим зовні цього корпуса. Вузол 14 виконує функцію опорного елемента хвостовика 12 шнека й функцію ущільнювального елемента, який виключає можливість проникнення атмосферного повітря усередину корпуса 1 через сполучення «отвір у корпусі 1 - елемент 14 - хвостовик 12».

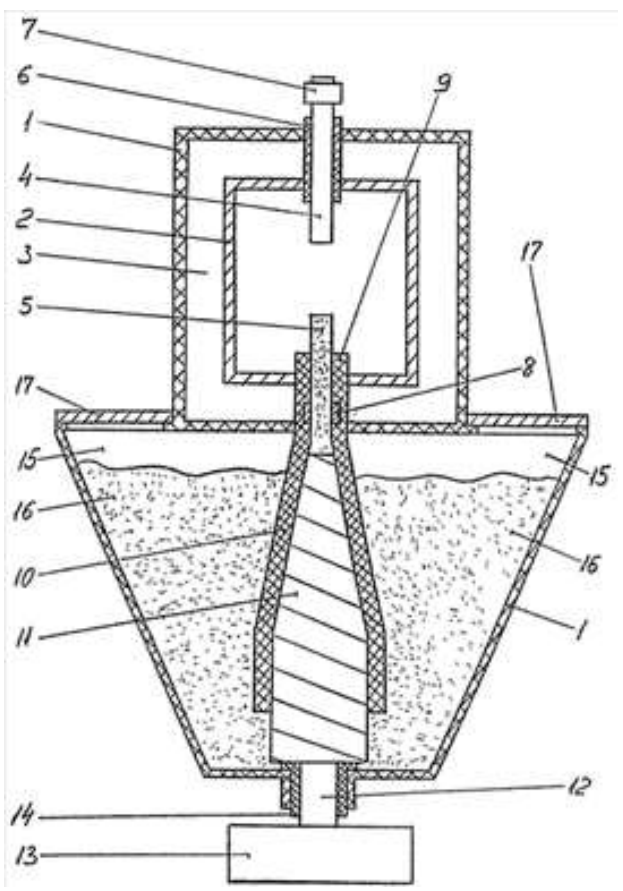

Рис. 3. Загальний вигляд установки:

1 - корпус, 2 - камера, 3 - порожнина для циркуляції води, 4-5 - електроди, 6 - ізолятор, 7-8 - струмопроводи, 9 - камера пресування, 10 - корпус преса, 11 - шнек, 12 - кулачковий вал, 13 - привод обертання, 14 - ущільнення, 15 - бункер, 16 - сипуча графітова маса зі сполучними добавками, 17 - кришка

У нижній частині корпуса $1 €$ бункер 15, який також входить до складу шнекового преса 10, 11. Бункер сполучений 3 нижньою циліндричною частиною преса й призначений для завантаження в нього сипучої маси 16, що містить графітовий порошок. Maca 16 призначена для формування електрода 5 .

Використовувана для роботи пристрою графітова маса 16 змішана зі зв'язувальною речовиною - кам'яновугільною смолою, пеком, що $\epsilon$ залишком розгону цієї смоли або ін. 
Недоліками даного винаходу є:

- недостатня якість отриманих продуктів випару графіту (нанотрубок i фулеренів), пов'язана 3 необхідністю додавання до графітового порошку зв'язувальної речовини, що забруднює отримані продукти й знижує їхній вихід;

- застосування шнекових пресів для пресування графітових стрижнів у камері випару реактора, як пропонують автори прототипу, може привести до спікання суміші до виходу з пресувальної камери, i, як наслідок, до зупинки його роботи. Цим пояснюється недостатня надійність пристрою.

Висновки. Порівняння результатів роботи установок показало, що найпростішим і найпродуктивнішим серед відомих є електродуговий метод одержання нанотрубок i фулеренів. Однак вихід корисних продуктів не перевищує $15 \%$.
Крім того, велика кількість конструкцій реакторів для одержання ВНВ свідчить про те, що дотепер не знайдена оптимальна конструкція, яка б гарантувала одержання продукту із заданими властивостями, стабільними параметрами та у необхідних кількостях.

Незважаючи на наявні результати численних досліджень, ВНВ поки що не мають широкого застосування на транспорті. 3 огляду на їхні унікальні властивості, застосування їх транспортному машинобудуванні можливо в найближчій перспективі.

Перераховані конструкції реакторів $\epsilon$ далеко не вичерпними, а розкриваються в статті лише тому, що можуть бути створені більш досконалі в найближчому майбутньому.

\section{Список використаних джерел}

1. Наноматериалы. Классификация, особенности свойств, применение и технологии получения [Текст]: учеб. пособие / Б.М. Балоян, А.Г. Колмаков, М.И. Алымов, А.М. Кротов. - М.: Наука, 2007 - 124 с.

2. Способ и устройство для производства фуллеренов [Текст]: пат. 5587141 Рос. Федерация: МПК C01B31/02, В82B3/00 / Fumikazu Ikazaki; заявитель и патентообладатель Ген. директор промышленной науки и технологии. - заявл. 13.02.1995; опубл. 24.12.1996, Бюл. № 3. $-10 \mathrm{c}$.

3. Способ производства фуллеренсодержащей сажи и устройство для его осуществления [Текст]: пат. 2341451 Рос. Федерация: МПК С01B31/00, В82B3/00 / Болстрен Н.Н., Басаргин И.В., Богданов А.А., Седов А.И., Флиппов Б.М.; заявитель и патентообладатель Общество с ограниченной ответственностью "Научно-производственная компания "НеоТекПродакт". - № 2007112872/15; заявл. 30.03.2007; Бюл. № 4. - 23 с.

4. Способ получения фуллереносодержащей сажи и устройство для реализации этого способа [Текст]: пат. 2418741 Рос. Федерация: МПК С01B31/02, В82B3/00 / Буч Е.М.; заявитель и патентообладатель ИЛИП. - № 2009117493/ заявл. 29.04.2009; опубл. 10.11.2010, Бюл. № 6. -22 с.

Рецензент д-р техн. наук, професор М.П. Ремарчук

Воронін Сергій Володимирович, канд. техн. наук, доцент, завідуючий кафедри будівельних, колійних та вантажно-розвантажувальних машин.

Онопрейчук Дмитро В‘ячеславович, канд. техн. наук, доцент кафедри будівельних, колійних та вантажнорозвантажувальних машин.

Суранов Олексій Олексійович, інжненер.

Амінов Дмитро Олексійович, слухач НН ІППК, гр. МЗ-БКМ-Б-11.

Voronin S.V., cand. of techn. sciences; Onopreychuk D.V., cand. of techn. sciences; Suranov A.A. eng.; Aminov D.A. 